\title{
Nadine Gordimer and the Force of Law: Revisiting My Son's Story
}

Audrey J. Golden

\section{(2) OpenEdition}

1 Journals

Electronic version

URL: https://journals.openedition.org/ces/431

DOI: $10.4000 /$ ces.431

ISSN: 2534-6695

\section{Publisher}

SEPC (Société d'études des pays du Commonwealth)

\section{Printed version}

Date of publication: 10 June 2019

Number of pages: $75-89$

ISSN: 2270-0633

\section{Electronic reference}

Audrey J. Golden, "Nadine Gordimer and the Force of Law: Revisiting My Son's Story", Commonwealth Essays and Studies [Online], 41.2 | 2019, Online since 05 November 2019, connection on 16 July 2021 URL: http://journals.openedition.org/ces/431 ; DOI: https://doi.org/10.4000/ces.431

\section{(c) $($ () $\ominus$}

Commonwealth Essays and Studies is licensed under a Licence Creative Commons Attribution - Pas d'Utilisation Commerciale - Pas de Modification 4.0 International. 


\section{Nadine Gordimer and the Force of Law: Revisiting My Son's Story}

Nadine Gordimer never gave up on the notion that new modes of justice for racial vio-

lence are linked inextricably to literary production. This essay draws on her novel My Son's

Story (1990) to demonstrate how Gordimer remakes the law as an ameliorative force that undermines the "vocabulary of violence," as she once described it, through which apartheid-era law was created.

The language of law itself cannot produce political change, Gordimer suggested at the Oslo Conference in 1990: "[T] [...]. And all of us who are sincere in the will to create a new South Africa are pledged to that end, not as some rhetorical ideal [...] but as a series of practical acts that will be carried out against all odds" (Gordimer, "After Apartheid"). Given Gordimer's insistence that we move beyond political rhetoric and toward practical action, readers might be surprised that she left Oslo to continue work on a novel. Gordimer never gave up on the notion that new modes of justice for racial violence are linked inextricably to literary production. Indeed, in personal correspondence with the author shortly before her death, Gordimer confirmed to me that George Bizos, Nelson Mandela's eminent attorney, drafted the legal language in much of her fiction. ${ }^{1}$

Toward the end of the final State of Emergency in South Africa, Gordimer began writing My Son's Story (1990), a novel that ultimately was published just after Nelson Mandela's release from prison. The novel thus inhabits a distinct temporality - or atemporality, as I will argue here - in which the end of the violent, racist law of apartheid was in sight and the concept of a free South Africa was coming into existence. In this liminal moment, I contend that Gordimer uses fiction to reveal the possibility for a literary "force of law." This is not to say that Gordimer did not find power in the law. In fact, in addition to asking Bizos to prepare the legal language in her fiction, she often was preoccupied with its legitimacy, noting in manuscript edits, for example, "as this is a quote from a law it must be accurate" (Gordimer, "After Apartheid"). Gordimer's concern with the credibility of legal language in her fiction underscores how she sought to wield the power of law within literature.

This essay argues that fiction can produce new ideas for developing a force of law outside the ideological constraints of geopolitical time. In the essay, I consider Jacques Derrida's assertion that law in the abstract inherently is tethered to a history of lawenforcing violence, and that as a result the law lacks capacity to produce justice. Breaking free from the ideological boundaries of apartheid lawmaking and law enforcing, My Son's Story develops a new model of time-space that is free from those ideological controls. The novel is able to perform this task in part because of the moment when it appears: in 1990, the apartheid system is on the brink of yielding to a democratic South Africa. Operating within this liminal opening, I argue that that novel generates a new literary time-space that I will call the "Zero chronotope" in which law as a historical

1. Personal correspondence with the author, July 2013.

2. The term "force of law" derives from Derrida's lecture, "Force of Law: The Mystical Foundations of Authority." 
construct can be destroyed and a new force of law can arise. ${ }^{3}$ The Zero chronotope refers to a temporal point of origin that is tied neither to what has come before it nor to what will follow - a moment of suspension. Hannah Arendt discusses such a period of suspended time and its political uses, describing an

odd in-between period which sometimes inserts itself into historical time when not only the later historians but the actors and witnesses, the living themselves, become aware of an interval in time which is altogether determined by things that are no longer and by things that are not yet. In history, these intervals have shown more than once that they may contain the moment of truth. (9)

To be clear, the essay does not suggest that a novel like My Son's Story can be treated as an alternative to existing law. Rather, I contend that My Son's Story, and other fiction that might produce a Zero chronotope, offer new ways for conceiving of laws that might push back against the harms of laws created - consciously or subconsciously - within the confines of racist ideology. In other words, we might view a work of fiction like $M y$ Son's Story as offering a new model for jurisprudence and, accordingly, a new theoretical base from which laws might be written, enacted, and enforced.

I begin by looking at the scholarly reception of My Son's Story, explaining how attention to the novel largely has been limited to a particular period in South African history. I seek to reinvigorate interest in My Son's Story, exploring its capacity to speak to political power beyond the historical moment in which it initially appeared. Next, I assess Derrida's discussion of the force of law, showing how an alternate, ameliorative force of law requires a new conception of time-space. From here, I consider the ways in which literary time-space, or Mikhail Bakhtin's model of the "chronotope," might help us to conceive of the Zero chronotope in My Son's Story. Finally, I turn to the text of the novel to demonstrate how it breaks down historical conceptions of "the law" and develops the Zero chronotope in which a new force of law might arise.

\section{Recovering My Son's Story from South African History}

Since the publication of My Son's Story, the novel has occupied a distinct political position in Gordimer's catalogue of work, largely tied to the early years of free South Africa. This essay seeks to revive the novel from its historical fixity and to demonstrate how it offers a new way to conceive of literature's political power in resisting the ideological constraints of racist law. The novel tells the story of a father, Sonny, and his son, Will, living in Johannesburg during the final State of Emergency. Sonny, a "coloured" man who used to be a schoolteacher, has become involved in African National Congress (ANC) politics and has been imprisoned as a result of his activism. During his imprisonment, a white human rights activist named Hannah provides Sonny's family - Will, but also Sonny's wife, Aila, and daughter, Baby - with information, and regularly visits Sonny in prison. After his release, Sonny begins an extramarital affair with Hannah, during which time Aila becomes an ANC activist in secret and Baby leaves South Africa. By the end of the novel, Sonny's affair with Hannah has ended unceremoniously, Aila has gone into exile after her arrest for political activism, and white residents have fire-

3. Bakhtin notably defines the "intrinsic connectedness of temporal and spatial relationships that are artistically expressed in literature" as a "chronotope," or "time space" (84). For detailed analyses of Bakhtin's chronotope, see, for example, Bemong et al, Falconer, Holquist, and Steinby. 
bombed Sonny's home, leaving it in ruins. Will, the narrator, ultimately becomes a writer himself and a critic of the apartheid regime.

In the early 1990s just after the novel's release - at a moment when a democratic constitution and models for remedying the harms of apartheid were taking shape numerous scholars examined My Son's Story through the lens of contemporary South African politics. Stephen Clingman, a long-time reader and critic of Gordimer's work, suggested that it depicted an intellectual or theoretical engagement with a specific liminal moment: apartheid was ending but a free South Africa had not yet come into existence. However, Clingman stopped short of suggesting that the novel could wield power beyond a mere thought exercise, describing the novel as inward-looking and "registering, in the main, 'mentality" (xxvII). Liliane Louvel observed how My Son's Story presented a microcosm for the newly free South Africa in which racial divisions remained, yet optimism reigned in looking toward the future (30). As Louvel argued, the text's fragmentary form and discontinuity in diction ultimately yield a formal reconciliation of sorts: " $[\mathrm{T}]$ he isotopy of fragmentation constitutes a unifying web structurally present at the level of story, text, and narration" (28). Similarly, Jorshinelle Sonza described My Son's Story as a novel tasked with "recording social and political events," like Gordimer's previous fiction, and "reconciling racial and gender conflicts" in free South Africa (105). Linda Weinhouse's scholarship on the novel attended more specifically to the limits of racial rapprochement in a newly free South Africa. Commenting on Gordimer's first attempt at writing a coloured male protagonist, Weinhouse underscored that, "despite the fact that the narrative demonstrates that the voice of the 'other' can be heard and imagined, Gordimer's attitude toward her own whiteness [...] is resentful and hostile" (71). Likewise, Ipshita Chanda questioned the larger-scale limits of racial representation and the "implications of Gordimer's work [...] for the milieu in which she lives," ultimately suggesting that My Son's Story attended to contemporary politics but had limited force outside Gordimer's committed readership (58).

Other scholarship addressed shifts in the South African constitutional law that sought to remedy institutionalized sex discrimination under apartheid, but nonetheless focused on what My Son's Story could tell its readers about gender-based equality. For example, K.C. Baral contended that the novel "propos[ed] a future South Africa, not only on terms of equality of races but of sexes, too" (123), while Nancy Topping Bazin considered the novel in relation to the politics of interracial sex on the cusp of the free South Africa's coming into being. Although she also discussed the post-apartheid political implications of the novel, Barbara Temple-Thurson saliently announced My Son's Story as "Gordimer's first unequivocally feminist novel" in her 1993 keynote address at the Conference on Commonwealth and Postcolonial Studies (5).

The novel largely fell out of favor with scholars interested in the political relevance of Gordimer's work in the wake of the South African Truth and Reconciliation Commission (TRC). In fact, only one peer-reviewed work returned to My Son's Story in the twenty-first century. After the initial close of the TRC in 1998, Lars Engle questioned the "utility and power of the Western literary tradition" - including Gordimer's fiction - given that the Western literary tradition long has been an "instrument of oppression" (114). In other words, he suggested that Gordimer's fiction might be relevant only in that it serves as evidence of its own political irrelevance in a period marked by Western neo-imperialism and racist law. I argue that My Son's Story not only has relevance for its 
own political moment, but that it also demonstrates a radical function of fiction across time and space.

\section{On Derrida, or the Force of Law in Literary Time-Space}

Given Derrida's contention that the law itself cannot produce justice, I want to consider whether alternative forms of language that are not, in the literal sense, law-creating might produce substitute models of legal language that can be used for ameliorative purposes. More specifically, I want to interrogate whether fiction, such as Gordimer's novel My Son's Story, might be able to conceive a force of law that resists the ideological constraints through which the language and function of racist laws of apartheid arise. This essay asks whether fiction can break down ideological borders of "the law" as a construct to produce an ameliorative political language that could better enable marginalized persons to exercise rights and privileges. The theoretical force of law was conceived by Derrida in a public address given in April 1990 shortly before the final State of Emergency ended in South Africa, and just a few months before Gordimer's previously quoted Oslo Conference remarks on the power of literature to make law. The address critiqued the theoretical concept of justice and its practical implications - a question looming large in South Africa at that time. Derrida's address, "Force of Law: The Mystical Foundations of Authority," revisits a Walter Benjamin essay, "Critique of Violence," to consider the limitations of law in producing justice. Derrida intimates that the law as we know it - a system of rules that governs persons, governs a nation-state inherently produces harm because of violence intrinsic to the term itself.

Even if laws are created to protect a vulnerable population, Derrida suggests that those laws by their nature necessarily include the notion of enforceability and thus preclude them from producing justice for marginalized bodies and voices. Enforceability in and of itself carries with it a capacity for violence and harm: "the word 'enforceability' reminds us that there is no such thing as law [...] that doesn't imply, in itself, a priori, in the analytic structure of its concept, the possibility of being 'enforced,' applied by force" (925). Derrida undercuts the oft-cited distinction between an ethical force of law that produces justice and the unjust violence that often is employed to enforce unjust laws and asks, "how are we to distinguish between this force of law [...] and the violence that one always deems unjust?" (927). This duality of law makes it impossible to "distinguish between the force of law of a legitimate power and the supposedly originary violence that must have established this authority and that could not itself have been authorized by any anterior legitimacy" (927). In sum, while it may be possible to conceive of a law designed and even put to use on behalf of marginalized groups, even that category of law - like all of law - already implies a violent force or enforceability. That potential for violence, Derrida argues, cannot be separated from the enforcing violence of racist law like that in apartheid-era South Africa. ${ }^{4}$ Given Gordimer's insistence on the power wielded by the law and legal language, it is important to raise potential objections to Derrida. Gordimer's concern with the law intimates that the latent potential for violence in the law may not be sufficient for considering it inherently flawed, as Derrida implies.

4. Gordimer herself might have been trapped by the ideological boundaries in which she wrote, given that she once imagined a fairer South Africa as one in which "a more equitable distribution of wealth may be enforced by laws" (Living 265). 
Rather, in Gordimer's estimation, the positive applications of law may, in some cases, outweigh the potential for violence contained within Derrida's conception of law.

In Derrida's conception, is there a possibility for an alternate force of law that inherently does good, or at least has the capacity to do so? I want to suggest that this possibility does exist and that it is tied to the notion of "originary violence" used by Derrida. Since all law as we know it inherently carries with it the "originary violence" of enforceability, to make law anew we must find a way to create a new origin story. Derrida intimates that law must take a new form if it is to do justice, and that it must be distinctly tethered to an immediate temporality that breaks from the past. ${ }^{5}$ That force of law must reconsider the very forms through which to produce justice for large-scale, racially motivated political violence since "there is no justice except to the degree that some event is possible which, as event, exceeds calculation, rules, programs, anticipations, and so forth" (971). Such an unexpected event, I argue, might occur in imaginative literature given fiction's "peculiar attribute of being able to stage and suspend all the presupposition upon which any such institution rests - among them the operation of laws" ("Before" 181).

By Derrida's account, connections among fiction, justice, and the force of law must not only conceive new formal structures, but also new approaches to time and temporality. ${ }^{6}$ Barbara Leckie observes how, for Derrida, both law and literature often are ideological prisoners to the sociopolitical conditions that have named them (40). ${ }^{7}$ As such, there is a salient need to break from a historical trajectory, developing instead an atemporal moment from which to make law and literature outside those ideological confines. When we talk about justice and temporality with regard to fiction, need we address temporality only within a work of fiction, or must we also look to the temporal moment in which a work of imaginative literature was produced and circulated? I contend that both the fictional time-space - the Zero chronotope - of the novel, as well as its geopolitical time-space, are necessary to consider how an alternate force of law can arise in fiction.

My Son's Story offers the possibility that both the political-historical moment in which a novel is written and circulated, along with its content, together give rise to new literary time-space models, which in turn can yield new ideas for political engagement. In considering whether Gordimer's fiction can give rise to an alternate, ameliorative "force of law," I maintain that time and space - both within and outside the novel play an essential role in breaking down ideological boundaries. Can a novel construct alternative historical time, thereby opening up opportunities for political resistance? Frederick Cooper discusses the need to produce new historical time that is not marred by a violent colonial past. Previous scholars have had "difficulty in separating the asymmetry of power from a totality," Cooper argues, given that "they can show that

5. Derrida writes of the immediate but elusive temporality of justice: "justice remains, is yet, to come," yet "however unpresentable it may be, doesn't wait" (969). Elisabeth Weber underscores that, for Derrida, justice is "an infinite task and responsibility that $[\ldots]$ cannot be relegated to tomorrow" (38).

6. Scholars across disciplines have considered the implications of Derrida's "Force of Law" lecture with regard to literature and politics. Derek Attridge intimates that there is a "force" of literary theoretical readings and of reader responsibility" (5-6). Samir Haddad emphasizes that Derrida's work on fiction is tied to practical concerns about violence, justice, and the law (122), while Barbara Leckie similarly argues both law and literature, for Derrida, "are deeply concerned with issues of representation in the service of participatory democracy" (111).

7. See Louis Althusser's Ideology and Ideological State Apparatuses, which details the ideological constraints that prevent us from thinking outside the state. In The Origins of Totalitarianism, Hannah Arendt maintains that the ability truly to think outside ideological boundaries marks the failure of a violent regime aimed at totality. 
such successful challenges to power as $[\ldots]$ anti-apartheid movements did not fully overthrow the inequalities they challenged or escape the frameworks of social order that imperial expansion produced" yet cannot articulate why in terms of the temporality and shape of historical moments (31).

My Son's Story presents a unique opportunity to consider the function of imaginative literature in responding to contentions like Cooper's. This argument has two necessary components. First, the novel produces a new temporal moment, tied neither to past nor present. The novel was written and published during the moment between apartheid ending and free South African coming to fruition - what Gordimer might have described, along with critics of her work, as an "interregnum." Yet the use of the term "interregnum" is tied distinctly to a past and future. I argue that the marked political break after apartheid ends yet before a free South Africa comes into existence is so precarious that it might be conceived of as atemporal, or a moment that cannot be tied to a past and may not produce a knowable future. Accordingly, that Gordimer writes and publishes My Son's Story at this moment might allow it to exist in an almost atemporal space where ideological pressures of past and future briefly relent. Second, it is precisely this moment of suspension that falls between the end of the final State of Emergency and the official dismantling of the laws of apartheid that gives the novel the ability to develop the internal Zero chronotope.

To explain how the Zero chronotope of My Son's Story might open up new ways of conceiving a legal or political function of fiction, I want to turn briefly to the theoretical underpinnings of Bakhtin's chronotope and the notion that aesthetic texts might produce alternate and necessary historical time. That aesthetic or literary works might create new time-space models to resist existing political ones is well studied across fields. As George Kubler wrote of visual art, "the number of ways for things to occupy time is probably no more unlimited than the number of ways in which matter occupies space" (96). Kubler intimated that art can push back against Western historical trajectories of time and space given that "[h]istory has $[\ldots]$ no theory of temporal structure" (96). Accordingly, aesthetic works can produce new visualizations of time-space patterns, or even seemingly nonexistent atemporalities in which "[a] rapid succession of events is a dense array; a slow succession with many interruptions is sparse" (97). Kubler's critique suggests that new temporalities can arise outside any known temporal structure. I want to build from here, considering temporal moments that not only are outside any temporal structure, but that also resist the products of abutting temporalities.

Can fiction really inhabit, and potentially create, a chronotope that exists outside the historical-political forces pushing on either side of it? In the case of My Son's Story, can fiction produce the Zero chronotope, which operates outside the bounds of traditional historical time and allows for the creation of a new "force of law"? Bakhtin lays the theoretical groundwork for such a possibility when he suggests that imaginative literature can produce "time-sequences that are neither historical, quotidian, biographical, nor even biological and maturational" (91). Indeed, "actions lie outside these sequences, beyond the reach of that force" (91). And perhaps most importantly, Bakhtin explains how these time-sequences can exist outside the ideological constraints of a past or future: "This empty time leaves no traces anywhere, no indications of its passing. This, we repeat, is an extratemporal hiatus that appears between two moments of a real time sequence" (91). In this way, a Zero chronotope might resemble what Bakhtin describes 
as an "alien world: everything in it is indefinite, unknown, foreign" (101). In such an "alien world," Bakhtin suggests that the "heroes are there for the first time; they have no organic ties or relationships with it; the laws governing the sociopolitical and everyday life of this world are foreign to them" and thus have the capacity to think and to create outside them (101).

Bakhtin's work intimates that literary fiction need not carry historical traces, challenging Walter Benjamin's claim that, always, "the past carries with it a temporal index" (Benjamin, "Concept" 1). It is through the alien chronotope, Bakhtin suggests, that the reader might access "the earliest traces of historical time" (129). Fiction makes it possible, in other words, to develop a time-space orientation that is outside one marked by a historical trajectory and its accompanying ideological constraints. Indeed, the chronotope developed by a fictional work can become "the boundary line between two epochs" (158). Bakhtin ultimately implies that literature gives us an opportunity to deny the temporal linkages that require an "earlier" and a "later"; instead, the novel might generate a chronotope that exists outside those temporal linkages and thus is free of ideological pressure. (158). The fact that "the represented world" in narrative fiction, "however realistic and truthful, can never be chronotopically identical with the real world it represents" (256), is precisely where the power of My Son's Story lies. Since it is always already outside of the real world despite referring to it, fiction has the ability to produce a new origin story, or the kind of "originary violence" that Derrida suggests is necessary in any definition - or re-definition - of the law.

Here, Gordimer readers and scholars might think specifically about the "interregnum." In 1982, Gordimer gave the lecture "Living in the Interregnum" in which she defined the state of "interregnum" as one "not only between two social orders but also between two identities, one known and discarded, the other unknown and undetermined" (269-70). In using the term, Gordimer referred to what seemed like looming revolution in South Africa to overthrow the apartheid regime. While the term certainly speaks to an "in-betweenness," the "interregnum" is tied indelibly to material and historical temporalities in a way that I want to resist. To be sure, Gordimer further discusses the "interregnum" as the "perceptual clutter of curled photographs of master and servant relationships, the 78 rpms of history repeating the conditioning of the past" (270). Since "literary standards and standards of human justice are hopelessly confused in the interregnum," and because it is a condition "imposed by history," the "interregnum" cannot be a time-space in which law can be made anew $(268,275)$. While the Zero chronotope invokes Gordimer's use of the term "interregnum" in its discussion of an inbetween time-space formulation, the Zero chronotope pushes back against any tethering to historical time. To be clear, while the term "interregnum" has been used to describe the transition between apartheid-era and free South Africa, I contend that the Zero chronotope is distinct from an interregnum as Gordimer and other critics have imagined it. The interregnum suggests a space clearly bracketed by a past and future - clearly situated temporally. The fact that a moment occurs between two distinct periods does not render it atemporal. The Zero chronotope, differently, refers to a moment that presents such a crucial break from the past that a future may not be conceivable. It is within this type of space that the atemporality of the Zero chronotope becomes a possibility.

Given Gordimer's emphasis on living in an "interregnum" prior to the end of apartheid, her fiction has long been the subject of scholarship on political temporalities, 
yet none has yet addressed the role that time and space, or the Zero chronotope more specifically, might play in giving rise to an ameliorative force of law. For example, Eleni Condouriotis observes how Gordimer's fiction puts an "added burden on the reader to integrate disparate histories across different narrative traditions, suggesting a method of reading that approximates cosmopolitan practice in the real world" (3). Discussing Gordimer's novel July's People (1981), Nasser Mufti argues that the end of the narrative "promises a termination to what Gordimer described as an 'interregnum,' a transitory stage between the two regimes" (64). Mufti emphasizes that the term "interregnum," borrowed from Gramsci, inherently connotes a momentary period tied both to past and to present in which "law is not at a 'standstill,' but it is precisely what is contested - will it apply to the old or new regime?" (65). In Mufti's view, the "interregnum" that Gordimer depicts in July's People is not free from the hegemony of the law, and thus cannot be free from ideological constraints (65-6). Even reading Gordimer's work through a Bakhtinian lens, few scholars have considered the ways in which her fiction develops new chronotopes outside the specific geopolitical moment of apartheid and its aftermath, concentrating instead on a compression of past and future. For instance, Mari-Ann Berg describes the mind of Gordimer's narrator in the short story "An Image of Success" as a "chronotope, or timeplace, in its own right," focusing on the "hereand-now" containment of the narrator's position. Andrea Spain likewise observes the altered temporality of the condition of postcoloniality in Gordimer's fiction and "the force of time, the virtual past insinuating itself within the present" (749). Most prominently, perhaps, Clingman has asserted that Gordimer's writing is "always in some way in dialogue with an absent future" ("Writing"13).

Other scholars have taken less nuanced views of the temporalities within Gordimer's fiction, arguing how, for instance, "Gordimer remains identified with her muscular political novels that chronicle the depredation of apartheid" (Naparstek 67). Timothy Brennan observes how Gordimer's novels engage with two kinds of laws: the laws of apartheid in South Africa, and the laws of realist writing in the twentieth century (756). Both points suggest that Gordimer's fiction is temporally fixed, existing firmly within the bounds of a known historical temporality. J.U. Jacobs, too, argues that Gordimer's novels are "overtaken by history," with fiction that indelibly intertwines apartheid-era legal and literary language (25-6).

In the most basic terms, my use of the term "literary language" refers to the narrative language used to produce fiction. A specific description of literary language, Gordimer suggests, is difficult if not impossible to produce given that literary language is ephemeral and necessarily contains a "transforming imaginative dimension" (Writing 22). Gordimer distinguished between literary language and testimonial language, the latter of which might create a practical record with historic and legal gravity (24). In distinguishing between the two, she suggested there is a sense in which literary language is subjective, always subject to interpretation, while legal language is in some capacities fixed and objective. Accordingly, on its surface, literary language is language that does not carry immediate weight under the law and is distinct from the legal language in its practical application. Yet part of my goal in this essay is to underscore the false binary between literary and legal language. If we presume that legal language carries a single, objective meaning while literary language has the capacity to produce multiple meanings, we as readers risk making ourselves complicit in perpetuating the notion that ima- 
ginative literature cannot inform political thinking. Bizos saw value in incorporating the distinct language of the law into Gordimer's fiction, and Gordimer emphasized how, in a novel, "a single word had weight" much as in a legal statute (My Son's Story 42).

My Son's Story develops language within its narration that eschews both the legal language of apartheid-era South Africa (and other racist regimes) and the literary forms associated with canonical English literary studies. Sonny, a character who was "once a great Shakespearean reader, reverent amateur of the power of words," discovers that "if a term is coined it creates a self-fulfilling possibility and at the same time provides a formulation for dealing with it" (179). Gordimer intimates that a political-literary space defined by the Zero chronotope is no place for Shakespeare or for other names and texts that have become tropes in literary study. Instead, the intertwining of language that at once refuses and draws from both legal and literary language of the past underscores the need for new language and new reading practices in the Zero chronotope: "All the movements and syllables that had sounded there, all that had happened there, caught in confusion, eddying without sense, motes drifting within the walls, falling back from them. That's what's over. That's the past, its dust not settled" (238). Analysis and critique of knowable literary forms, like syllables and stress patterns, become moot. At the same time, legal language as it has become known - or that language used for purposes of enacting and enforcing racist law - must be discarded. Indeed, at one point in My Son's Story, the narrator rejects language altogether in favor of a seemingly universal symbol; the word "love" (or one of its synonyms) is replaced with an image of a line-drawn heart (231). The third-person narrator in My Son's Story refers to the "detritus of common usage" employed by "the lawyer and estate agents and municipal officials" (11).

Rather than reading My Son's Story as a novel that integrates past, present, and future histories of South Africa, or that reflects contemporary politics in its language, I contend instead that this particular novel divests itself of past and future, developing the Zero chronotope that resists ideological boundaries created by past law and by the future laws of reconciliation that are to come. In so doing, Gordimer produces new language that speaks to tropes of both legal and literary discourse, demonstrating the intertwined nature of imagination and justice within the Zero chronotope. In My Son's Story, for example, Gordimer insists that Sonny must redefine known English language for himself given the atemporality of the political moment in which he exists. The narrator explains that "Sonny had to define to himself what he meant by "before" because "there was a blank in his chronology" (257). It is not that Gordimer finally locates a political and literary moment to depict the "new that cannot yet be born" as she does in July's People, but rather that she locates a moment to create a newness that resists the confines of past and future ("Living" 266). As Frederick Cooper observes, "historical temporality $[\ldots]$ is 'lumpy': the tendency for innovation and breaks to be reabsorbed into ongoing discursive and organizational structures is sometimes broken by a cascade of events that reconfigures the imaginable and the conceivable" (21). Citing Gordimer's own words, Andrea Spain emphasizes how "Gordimer asks us to become open to "learning to think outside the way our society [is] ordered, to reimagine modes of living that might alter normality rather than reinforce its permanent alteration of subaltern lives in uneven development" (749). It is with this notion of "learning to think outside" that I want to turn to the text of My Son's Story to demonstrate how it breaks down the 
ideological constraints of the law and develops a Zero chronotope in which an alternate force of law might come forth.

\section{Revisiting My Son's Story}

My Son's Story demonstrates how literature, arising out of a distinct time and place, might produce a Zero chronotope that offers an opportunity to reimagine the force of law. This process begins as Gordimer reveals the ideological trappings of the law - and its predecessors and successors - to confirm Derrida's intimation that such a thing as a "just law" cannot exist in current formulations. For example, characters in the novel reflect on a common dictum:

When people make violence the ultimate test of who's right and who's wrong here - you know the argument I mean - "the struggle is no better than the oppression because violence on the part of the oppressed can never be justified," it reduces them to the level of the oppressor and so on. (127)

Indeed, the novel even goes so far as to suggest that members of the government and the resistance alike are put into those positions not by their own accord but instead through the ideological foundations of apartheid law. During the "States of Emergency in the country," Gordimer writes, "it is the enemy - the police, the Ministers of Law and Order and Justice - who decides who the leaders of the people are" (262-3). Yet there may be ways to break free from those ideological constraints. Violence - a new "originary violence," as Derrida might describe it - must be enacted upon known literary forms and methods of meaning-making that have been produced by the very ideological constraints that the violence seeks to disrupt. By breaking down these structures, the novel might be able to begin anew, outside the bounds of ideology. ${ }^{8}$ The power of the novel lies ultimately in the possibilities it reveals for, rather than its ability to create, a force of law.

To develop a Zero chronotope, the novel first must reveal the ideological trappings of law, and mark them for destruction if a new force of law is to arise. These ideological boundaries of the law show themselves as both physical, geographic borders and subordinating identity borders placed upon nonwhite bodies in South Africa under apartheid. For the protagonist's family, "the meaning of life seemed to be contained [...] and that could only mean the community to which they were confined, to which they belonged because the law told them so" (9). Gordimer illumines how spatial restriction becomes more insidious, ideologically shaping the identities of those confined within segregated space. As a result of his containment by the law, in the "sub-division of blackness decided by law" (65), Will only fantasizes about blonde, white women, whom he describes as "an infection brought to us by the laws that have decided what we are" (14). In all spaces of the novel - public and private, communal and domestic - the characters innately know: "The lawyer [...] he was the power," and the term lawyer cannot shift from the denotation of a white man; others excluded from this definition also are excluded from positions of power as defined by the law (232).

The racist law of apartheid is not defined solely by this regime, however. The law of apartheid contains within itself the enforceability of racist laws of the past, reflecting

8. Steve Biko argued that the "banner of liberal ideology" among whites in South Africa, despite resisting apartheid in name, only served to underpin the enforcing violence of apartheid law (64). 
Derrida's contention. Apartheid law inherently is tethered to the laws of imperialism, colonization, and racist exclusion developed along a historical trajectory, and across various geographic spaces. To be anything other than white in South Africa, the novel tells its reader, is to be "judged by the laws white men made for us" (261). In this way, the term "the lawyer" becomes tied to the pejorative enforceability of the law and its historical antecedents. Indeed, "white industrialists, churchmen, academics, liberals and lawyers: they were people belonging to professional and social structures within the law" (267). Sonny awakens at one moment in the novel to realize the historical layers of South African law, and the manner in which law as a construct necessarily contains within itself the racist lawmaking violence that self-perpetuates white power across time and space:

There flashed and plunged behind his closed eyelids a broken sequence of men with white rags tied across their faces in torchlight, men on horseback carrying their flag with its emblem of the swastika, the deformed shape twisted once again to the same purpose. White extremists were rallying to that sign; blacks who had moved into white neighborhoods were suffering threats and vandalism beneath it. And fear, fear. (265)

Lawmaking violence is tied to white power along a historical trajectory; apartheid law cannot be separated from its links to the Nuremberg laws in Nazi Germany, Jim Crow laws promoting violence and discrimination against African Americans in the U.S. through much of the twentieth century, and laws that facilitated the transatlantic slave trade more than a century prior." To be sure, Sonny "knew as a commonplace sight a barefoot man hobbled by ankle chains shuffling as a horror risen from the slave past into the memory of computers and the glare of the strip lighting in the anteroom" (228). Yet that law as a singular, layered historical entity need not have infected the fiction that critiques it, Gordimer suggests. Given the possibility that imaginative literature might break free from ideological pressure, it also becomes a site in which the force of law might be made anew. Yet to remake the force of law with an eye toward justice, the fiction first must enact a new kind of "originary violence" from which it can begin again, and this new violence must occur in the literary Zero chronotope.

Sonny develops the power to redefine literary language - the language through which characters speak to "chronicle otherwise unknown human experience," as Gordimer describes it (Writing 23) - and to instill that power in others:

If he used the vocabulary of politics because certain words and phrases were codes everybody understood - no interpreter necessary, even in the English in which they were formulated they expanded in each individual's hearing to carry the meaning of his own frustrations, demands and desire. (112)

Indeed, the novel explains how, as a "reverent amateur of the power of words, Sonny must have known that if a term is coined it creates a self-fulfilling possibility" (179). The political power of literary language becomes more pronounced when "long wails of terror," produced by apartheid law, "were cut through by the dry syllables of shots, a sound hard as the steel that flies and pierces flesh and bone, goes to the heart that is bursting with the effort to run away and to the throat where the yell rises" (emphasis added, 116).

9. Gordimer previously discussed the "interregnum" as being tied to a global history of oppression: "An extraordinarily obdurate crossbreed of Dutch, German, English, French in the South African white settler population produced [...] apartheid, coining the ultimate term for every manifestation, over the ages, in many countries, of race prejudice. Every country could see its semblances there; and most peoples" ("Living" 262). 
This literary language is made possible by the Zero chronotope of the novel. My Son's Story inhabits this Zero chronotope, an atemporal space into which the law increasingly has difficulty reaching, marked by an aggressive, intentional stagnation of time: "Waiting. All, like them, waiting" (225). This atemporality that defines the Zero chronotope is denoted also by a constant inconclusiveness of time, preventing the reader from situating the particular moment through context clues to past or future: "a matter of 'at that time' and 'then'; qualifications and uncertainties" (87). While apartheid law governing South Africa, and any attempts within the system to change that law, necessarily bear traces of the historical violence of lawmaking and law enforcement, the Zero chronotope of My Son's Story comes to exist outside it. Both Sonny and Will recognize traces of the compressed historical temporality in their present, like those allusions to law in Nazi Germany or laws of enslavement, but they nonetheless come to inhabit a more atemporal space in which they can produce language and knowledge that is free of those ideological constraints. Indeed, once Aila is arrested for political resistance, "Sonny had to define to himself what he meant by "before" given that "there was a blank in his chronology" (257). Considering his newfound ability to act politically after Aila's arrest, Will reflects on his own power "[s]o long as the length of time that had passed was not measured" (260).

This unfixed political temporality - or atemporality - is defined in part by Sonny's relationship with Hannah: "Its very intensity was granted on the condition that it could not last. Everything outside was ready to rupture it" (72). That there is a brief, limited time in which to reimagine an alternative force of law is underscored by the temporal liminality of the political period itself in which the novel is written and published: "A man who has been convicted of a crime against the State will continue to be watched as long as his life or the State that convicted him lasts; whichever endures the longer" (82).

The power of literary language to redefine, do violence upon, and ultimately reconstruct the layered historical systems of language that make the law leaves the novel in a place from which language can begin anew. This place becomes the definitive marker of the Zero chronotope. It is at once a new political time-space, yet also literary time-space that acknowledges the previous power of fiction. By the end of the novel, Will recognizes the Zero chronotope as giving rise to new linguistic meaning, given that "there were no categories of ownership or even usage left" (273). While the plot of the novel ends with a fire that destroys Sonny's family home, Will links the "smell of destruction, of what has been consumed" with the possibility for new creation outside the boundaries of ideology with a directive to the reader: "we're that bird, you know, it's called the phoenix, that always rises again from the ashes" (274).

In a final reflexive move that underscores the ability for literary language to take on political force through the Zero chronotope, an epigraph of sorts tells the reader that "grammar is a system of mastering time" (275). Accordingly, in mastering time, fiction also has the power to change the temporality of law and history. Here the reader is invited to return to earlier moments in the novel that prophesy the power both of the political moment in which the novel appears, and the Zero chronotope within which the characters develop the power to speak and to act against the law that pejoratively defines them. The narrator reminds the reader of fiction's historic power throughout the novel, noting that "Kafka named what he had no names for" (17), and that Sonny "went to Shakespeare for a definition with more authority than those given on make- 
shift platforms in the veld" (23). Those who assume otherwise about literary language, the novel intimates, "people like that are so naive [...]. [T] hey haven't lived enough to connect words with the reality of acts" (127). After all, Gordimer reminds her reader, "words, too, are stones" (32). This realization of the potential power of fiction is "the miracle that makes literature and links it with creation in itself in the biological sense" (275).

My Son's Story ultimately demonstrates how fiction can undermine the "vocabulary of violence," as Gordimer described it, through which apartheid-era law - and all law before it - was created. Gordimer's fiction develops new forms of "originary violence" with regard to formal structures of English literary language. In this way, Gordimer engages in lawmaking violence, as Walter Benjamin suggested was necessary to produce justice, without the harmful counterpart of law-enforcing violence, as Derrida argues. Gordimer's work shows how literature itself can develop the Zero chronotope in which an ameliorative force of law might be conceived.

In considering the possibility that Gordimer's fiction might enact a new force of law, drawing a line to Derrida is a natural connection. Both writers demanded that fiction should have a political function, and that fiction-making and law-making should be deeply interrelated. Discussing the interrelation of law and literature, Derrida explained: "What differs from one work to the other is not the content, nor is it the form [...]. It is the movements of framing and referentiality" ("Before" 213). Given current corruption within the ANC and the possibility of another political shift in contemporary South Africa, My Son's Story remains relevant in considering whether fiction has a role to play in re-producing the force of law that is responsible for yielding justice. On a larger scale, the possibilities presented by the Zero chronotope in My Son's Story also could have implications for fiction arising out of other moments of violence in far-reaching parts of the globe, speaking to liminal geopolitical moments occurring across the world in which there is a distinct need to produce a new, remedial force of law. At the same time, it is vital to distinguish between the theoretical ways in which literature can have transformative power, and the imperfect and often messy realities of political pragmatism. Fiction like My Son's Story can offer new ways of thinking, and can conceive of alternate ways of using language to make law. Yet the question of how - and whether - imaginative literature ever can have political currency in praxis is an inquiry we must approach tentatively. That Bizos saw value in producing legal language for Gordimer's fiction suggests that imaginative literature and law are interrelated, yet narrative language in fiction never can become a stand-in for a legal document that has immediate effects on very real persons, for instance. Instead, one of the important lessons that Gordimer's fiction teaches is that a novel like My Son's Story, in opening new ways of thinking, might be able to alter the theoretical positions from which law ultimately is created.

Audrey J. GoLDEN

Simmons University, Boston, Massachusetts

\section{Works Cited}

Althusser, Louis. "Ideology and Ideological State Apparatuses.” Mapping Ideologies. Ed. Slavoj Žižek. London \& New York: Verso, 1994. 100-39. 
Arendt, Hannah. Between Past and Future. New York: Viking, 1961.

—. The Origins of Totalitarianism. New York: Harcourt, 1973.

Atтridge, Derek. "Derrida and the Questioning of Literature." Acts of Literature. Ed. Derek Attridge. London: Routledge, 1992. 1-33.

BakHTIN, Mikhail. "Forms of Time and of the Chronotope in the Novel." The Dialogic Imagination. Trans. Caryl Emerson and Michael Holquist. 9th ed. Austin: U of Texas P, 1994.

Baral, Kailash C. "Happy for Battle: The Essential Gesture in Nadine Gordimer's My Son's Story.” The Literary Half-Yearly 34.1 (1993): 112-25.

Bazin, Nancy Topping. "Sex, Politics, and Silent Black Women: Nadine Gordimer's Occasion for Loving, A Sport of Nature, and My Son's Story." Black/White Writing: Essays on South African Literature. Ed. Pauline Fletcher. Lewisburg, PA: Bucknell UP, 1993. 30-45.

Bemong, Nele, et. al., eds. Bakbtin's Theory of the Literary Chronotope: Reflections, Applications, Perspectives. Hanover: UP of New England, 2010.

Benjamin, Walter. "Critique of Violence." Reflections: Essays, Aphorisms, and Autobiographical Writings. Ed. Peter Demetz. Schocken, New York: Schocken, 1986. 277-300.

—. "On the Concept of History." Walter Benjamin: Selected Writings, 4: 1938-1940. Ed. Howard Eiland and Michael W. Jennings. New York: Belknap, 2006.

Berg, Mari-Ann. "Exploring the Mind: Self, Other and Social Context in Nadine Gordimer's 'An Image of Success." English in Africa 29.1 (May 2002): 55-72.

Biko, Steve. "White Racism and Black Consciousness." I Write What I Like. Chicago: U of Chicago P, 2002. 61-72.

Brennan, Timothy. Review of The Novels of Nadine Gordimer, by Stephen Clingman. Modern Fiction Studies 34.4 (1988): 756-7.

CHANDA, Ipshita. "Speaking for Another: Nadine Gordimer's My Son's Story." The Literary Criterion 27.3 (1992): 56-70.

Cuingman, Stephen. "Nadine Gordimer: A Writing Life." A Writing Life: Celebrating Nadine Gordimer. Ed. Andries Walter Oliphant. New York: Viking, 1998. 3-18.

—. The Novels of Nadine Gordimer. $2^{\text {nd }}$ ed. Amherst: U of Massachusetts P, 1992.

Condouriotis, Eleni. "Rethinking Cosmopolitanism in Nadine Gordimer's The Conservationist." College Literature 33.3 (Summer 2006): 1-28.

CoOper, Frederick. Colonialism in Question: Theory, Knowledge, History. Berkeley: U of California P, 2005.

Derrida, Jacques. "Before the Law." Acts of Literature. Trans. Geoffrey Bennington and Rachel Bowlby. Ed. Derek Attridge. London: Routledge, 1992. 181-220.

—."Force of Law." Trans. Mary Quaintance. Cardozo Law Review 11 (1989-90): 920-1045.

Engle, Lars. "Western Classics in the South African State of Emergency: Gordimer's My Son's Story and Coetzee's Age of Iron." Thresholds of Western Culture: Identity, Postcoloniality, Transnationalism. Ed. John Burt Foster Jr. and Wayne Froman. New York: Continuum. 114-30.

FalCONER, Rachel. "Bakhtin's Chronotope and the Contemporary Short Story." South Atlantic Quarterly 97.3-4 (1998): 699-732.

Gordimer, Nadine. "After Apartheid: Black and White in a New South Africa." Draft of Address to the Oslo Conference, August 1990. The Nadine Gordimer Papers. Courtesy Lilly Library, Indiana University, Bloomington, Indiana.

—. July's People. New York: Viking, 1981.

—. "Living in the Interregnum." The Essential Gesture: Writing, Politics and Places. Ed. Stephen Clingman. New York: Knopf, 1988. 243-310.

—. My Son's Story. London: Bloomsbury, 1990.

-. Writing and Being. Cambridge: Harvard UP, 1995.

Holquist, Michael. "The Role of Chronotope in Dialogue." From Petersburg to Bloomington. Ed. John Bartle et al. Bloomington: Slavica, 2012. 114-30. 65-79.

JacoBs, J.U. "Gordimer's Intertextuality: Authority and Authorship in My Son's Story." English in Africa 20. 2 (1993): 25-45.

KubLER, George. The Shape of Time: Remarks on the History of Things. New Haven: Yale UP, 1962.

LeCKIE, Barbara. "The Force of Law and Literature: Critiques of Ideology in Jacques Derrida and Pierre Bourdieu." Mosaic 28.3 (1995): 109-36.

Louvel, Liliane. "Nadine Gordimer's My Son's Story or the Experience of Fragmentation." Commonwealth 14.2 (1992): 28-33.

Mufti, Nasser. "Reading the Interregnum: Anachronisms in Gordimer's July's People." Journal of Narrative Theory 43.1 (2013): 64-86.

Naparstek, Ben. "Nadine Gordimer at Eighty-Two." Tik.kun 21.3 (2006): 67-9.

SonzA, Jorshinelle T. "My Turn, Now: Debunking the Gordimer 'Mystique' in My Son's Story." Research in African Literatures 25.4 (1994): 105-16.

SpaIN, Andrea. "Event, Exceptionalism, and the Imperceptible: The Politics of Nadine Gordimer's The Pickup." Modern Fiction Studies 58.4 (2012): 747-72. 
Nadine Gordimer and the Force of Law: Revisiting My Son's Story

Steinby, Liisa and Tiinti KLApuri, eds. Bakbtin and His Others: (Inter)subjectivity, Chronotope, Dialogism. New York: Anthem P, 2013.

Temple-Thurston, Barbara. "Nadine Gordimer and a New South Africa." Journal of Commonwealth and Postcolonial Studies 2.1 (1994): 1-11.

WeBER, Elisabeth. "Deconstruction is Justice." SubStance 34.1 (2005): 38-43.

Weinhouse, Linda. “The Paternal Gift of Narration: Nadine Gordimer's My Son's Story." Journal of Commonwealth Literature 28.2 (1993): 66-76. 